5. A majority of participating students has been contacted by a number of graduate shcools

- Eighty-eight percent of the respondents reported being contacted by an average of 13 graduate schools, ranging from one to forty.

As in previous surveys, MID students were asked how the graduate school application and admission processes might be improved and what APSA could do to interest more minority students in political science careers. Many students again noted that their concerns about job prospects for political scientists had influenced their choices and suggested that APSA publicize more career information and stories of successful minorities in political science. They also emphasized the importance of mentoring by faculty and graduate students, exposing senior undergraduate students to graduate-level work, and simplifying/standardizing the application process.

For example, one student wrote, "I believe that more minorities would be interested in political science if they knew about the successful minorities in political science, both graduate students and professors." This student also commented that "graduate students would be of great value to undergraduates. Sometimes, seniors would like to hear from someone who has just gone through the same process as you are going through. Therefore, I would suggest that you compile a list of MID graduate students who are willing to talk to and counsel potential graduate students."

Another student commented that "I was fortunate enough to be able to do graduate-level work and research as an undergraduate. This level of training has taught me what kinds of things are expected by graduate students and what, exactly, professional political scientists do. When I was visiting various campuses, many of the other prospective students I met had no idea about the level of scholarship and research expected by graduate institutions. I think I would be in for a very big shock next year had I not had the exposure to this level of work as an undergraduate."

A third student noted that "Project 1000 has one application [form] that they accept and farm out to multiple schools. Most Vet schools also accept one application (that is posted on the web) and send it to the schools you request. The APSA could create a similar single application and, hopefully, over the years, multiple institutions would accept that application in lieu of their own. Naturally, each institution could request additional information. In short, fill out an application once, indicate the schools you want to apply to, and forget about it. Documentation, fees, letters of recommendation, will all also be handled by the student." This student also suggested that APSA "put together a packet indicating financial resources for minorities, mail it directly to students, and post it on the web."

To receive more information about MID, contact Titilayo Ellis (tellis@apsanet.org).

\section{Encouraging the Brightest: The 1999 Ralph Bunche Summer Institute}

\section{Michael Cairo, University of Virginia}

Fourteen gifted undergraduate students from colleges across the country attended the thirteenth annual Ralph Bunche Summer Institute at the University of Virginia this summer. Their mission: To learn more about graduate study in political science. Sponsored jointly by the department of government and foreign affairs at the University of Virginia and the American Political Science Association, the Bunche Institute is designed to introduce African American students to graduate school and to encourage their application to Ph.D. programs in political science. This year's class represented 14 schools as diverse as Swarthmore College in Pennsylvania and Santa Clara University to Spelman College in Georgia and Millikin University in Illinois.

While living on the grounds of UVA, students spent five weeks in

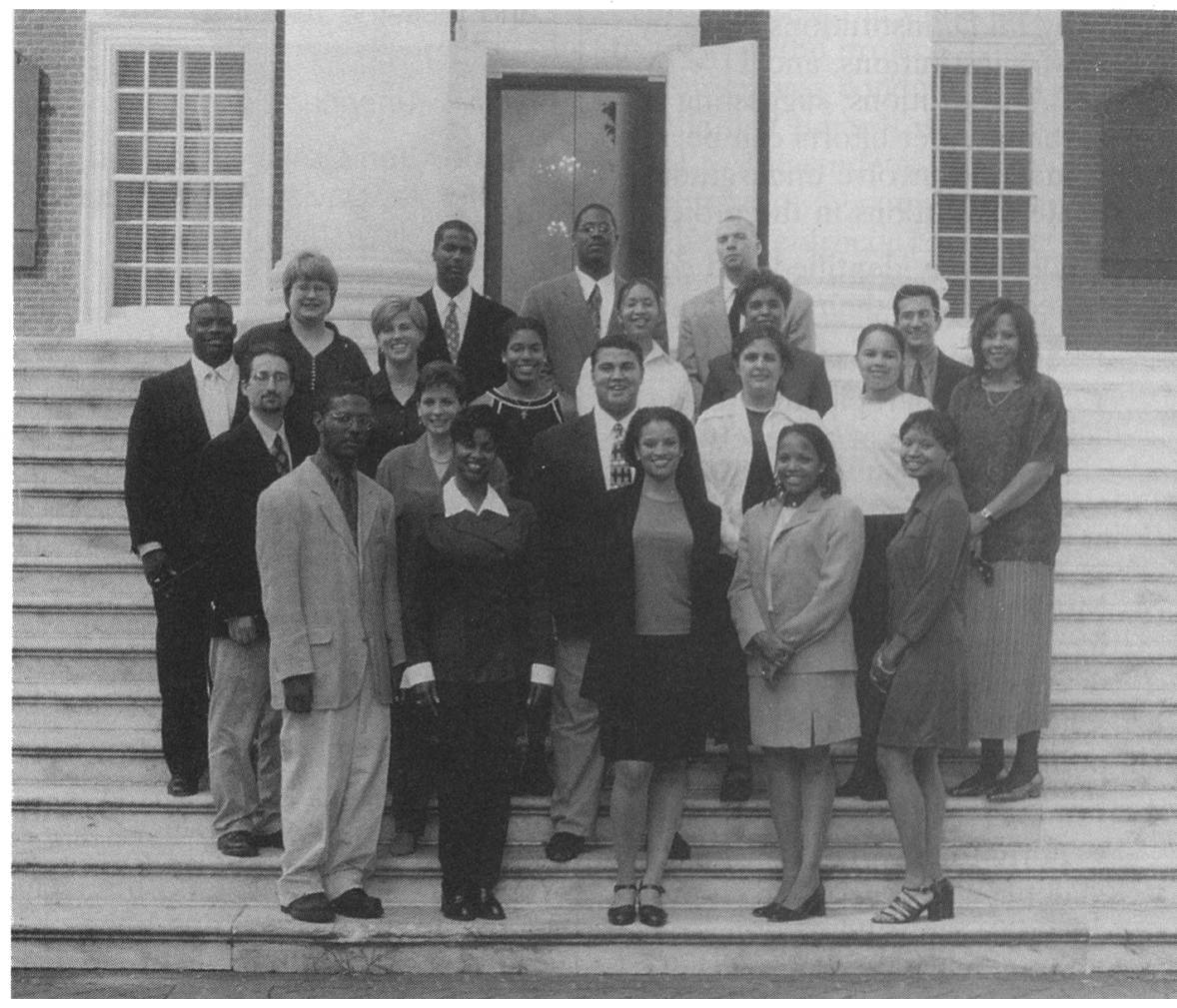

1999 Ralph Bunche Summer Institute participants and staff. Top Row (L-R): Jamarlin Muhammad, Berlin Vincent Kelly, Tyson Marsh. Third Row (L-R): J. Alan Kendrick (TA), Karen Cox (TA), Amy Stewart (TA), Conra Gist, Lynda Jackson-Sealy, Lisa Renee Jones, Michael Cairo. Second Row (LR): Prof. Paul Freedman, Stacy Nykios (TA), Rickey Williams Jr., Maria del Carmen Huerta, Christina Grant, Prof. Paula D. McClain (Director). First Row (L-R): Ronnie Booker Jr., DeAunderia Byrant, Sacajawea Hall, Crystal Curry, Janelle Banks. 
two graduate level courses taught by distinguished members of the Department's faculty, as well as attended weekly lunches and dinners with visiting scholars from all over the U.S. The students toured Monticello, Thomas Jefferson's mountain home, and traveled to Washington, DC, where Kaplan Testing Services provided the students with a Graduate Record Examination preparation course. And on June 25, representatives of 14 leading graduate political science programs came to UVA and attempted to recruit the students to their universities.

Study at the Institute was intense. Monday through Thursday the students met for four hours in either Institute Director Paula McClain's course on Race and American Politics or a quantitative methods course, Political Analysis, taught by Professor Paul Freedman. According to Bunche student DeAunderia Bryant (UC-Berkeley), it was "a challenging program which provides promise for a successful future in the field of political science." Tyson Marsh from the University of Washington added that "It [was] a valuable learning experience and is instrumental in shaping the young minds of minority students inter- ested in pursuing a career in academics."

This year's program also proved one of the most successful in convincing students to apply to graduate programs in political science. According to Christine Grant of Hofstra University, "It solidified my interest in pursuing a Ph.D. in the field of political science." Ronnie Booker of the University of Virginia commented that "as a result of participating in this program, it's certain that I want to pursue a career in academia."

All of the students also reported marked improvement in their writing and research skills. Janelle Banks of Smith College explained that the program "opened [her] eyes to the wide array of topics in the discipline of political science."

Because of its rigorous program, the Institute's past student-scholars have seen great success. Yvette Alex-Assensoh, an assistant professor at Indiana University, Heather Dash, a graduate student at Emory University, Khalilah Brown, a graduate student at Ohio State, and Andra Gillespie, an entering graduate student at Yale University, are all Bunche alumnae. Andra, Yvette, and Khalilah returned on June 25 to tell the students a little about how the Institute has impacted their

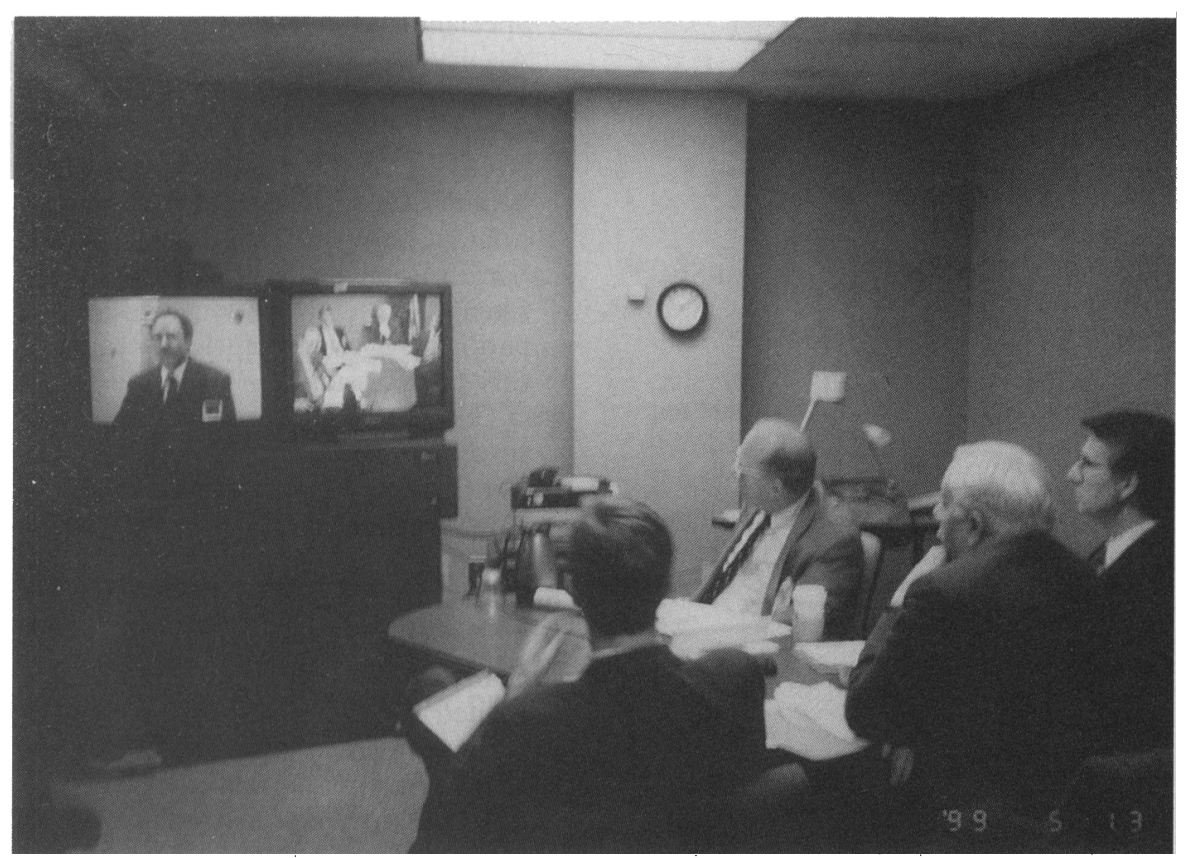

Members of the federal executive fellow selection panel conduct an interview via satellite teleconferencing with a USIA candidate at the agency's headquarters in Washington, DC. From the left: Chris Midura, USIA (CFP Fellow 1997-98); Professor Frederick Holborn, John Hopkins University; Edward Cole, U.S. Forest Service (CFP Fellow 1997-98); Jeffrey Biggs, CFP Director (CFP Fellow 1985-86). USIA Candidate Ken Moskowitz, U.S. Embassy, Vienna, pictured on screen.

lives. Many other students have had success in application to other top graduate and law programs over the past 12 years. In fact, a number of alumni have received master and Ph.D. degrees and three have been named assistant professors.

The Institute's namesake, Ralph Bunche, a 1934 Harvard University graduate, was the first African American to receive a doctorate in political science and the first to serve as president of the American Political Science Association. In 1950 he also became the first African American to receive the Nobel Peace Prize.

The Institute has been held at the University of Virginia for the past four years. The program is supported financially by a grant from the National Science Foundation, the American Political Science Association, and by the University of Virginia.

\section{Diversity and Internationalism \\ Characterize 1999-2000 Congressional Fellows}

Continuing to benefit from the very generous MCI WorldCom endowment of several years ago, the ongoing support of Congressional Quarterly, Inc., and a recently received three-year grant from the John S. and James L. Knight Foundation, the APSA Congressional Fellowship Program retains its core emphasis on providing political scientists and journalists the opportunity of experiencing Congress firsthand. Although those two groups have been present since the program's inception in 1953, the fortyseventh class of Congressional Fellows, who begin their orientation in November 1999, represent an increasingly diverse group.

For example, this is the second year the Congressional Fellows will include a Hatfield Fellow, named after former Oregon Republican Senator Mark Hatfield. The fellowship provides an Oregon Native American with a position on the legislative staff of an Oregonian congressional delegation. The fellowship switches chamber and political party each year. The Hatfield Fellow helps ensure the concerns of thousands of the region's Native Americans are- 